\title{
The Polycirrinae (Polychaeta: Terebellidae) from Australia
}

\author{
Pat Hutchings and Chris Glasby
}

Australian Museum,

P.O. Box A285, Sydney South, NSW 2000, Australia

\begin{abstract}
The polycirrine fauna of Australia comprises four genera and 22 species. These are described, and a key to the genera and Australian species are provided. Eleven new species are described: Hauchiella renilla $\mathrm{n}$. sp., Lysilla laciniata $\mathrm{n}$. sp., L. bilobata $\mathrm{n}$. sp., L. jennacubinae n. sp., Polycirrus bicrinalis n. sp., P. disjunctus n. sp., P. nephrosus n. sp., $P$. parvus n. sp., $P$. paucidens $\mathrm{n}$. sp., $P$. tesselatus $\mathrm{n}$. sp. and $P$. variabilis $\mathrm{n}$. sp., and the following new combinations, Amaeana apheles (Hutchings) and Polycirrus octoseta (Hutchings). A full description of all Australian species of this subfamily is given except when a recent full description is available. Comments are made on the variety of characters which have been used to describe species of Polycirrus and the value of these characters.
\end{abstract}

Hutchings, P.A. \& C.J. Glasby, 1986. The Polycirrinae (Polychaeta: Terebellidae) from Australia. Records of the Australian Museum 38(6): 319-350.

The Polycirrinae recorded from Australia prior to 1979 are listed by Day \& Hutchings (1979) and include six species belonging to four genera. In 1984 we began a revision of the family Terebellidae (Hutchings \& Glasby, 1986, in press), and by examining all the collections of terebellids housed in Australian Museums we have considerably expanded the polycirrine fauna of Australia. In this paper we describe 11 new species and synonymise the genus Litancyra Hutchings with the genus Polycirrus Grube.

The sizes of animals examined were measured as total body length excluding tentacles, maximum body width excluding notopodia, and the number of body segments. The Australian distribution of each species is indicated at the end of each species account, and exact localities are shown in Fig. 12. In cases where species are recorded from outside Australia, all existing records are indicated.

The following abbreviations have been used.

AHF Allan Hancock Foundation, Los Angeles

AM Australian Museum, Sydney

BMNH British Museum Natural History, London

CSIRO Commonwealth Scientific and Industrial Research Organisation, North Beach, Perth
HZM Zoologisches Institut und Zoologisches Museum der Universität, Hamburg

NMV National Museum of Victoria, now Museum of Victoria

NMW Naturhistorisches Museum, Wien

NSWSF New South Wales, Department of Agriculture, Fisheries Division

QM Queensland Museum, Brisbane

USNM National Museum of Natural History, Smithsonian Institution, Washington

UZM Universitets Zoologiska Museum, Uppsala

WAM West Australian Museum, Perth

ZMA Zoölogisch Museum, Amsterdam

ZMB Zoologisches Museum, Museum für

Naturkunde der Humboldt - Universität, Berlin

ZMO Zoologisk Museum, Oslo

$$
\text { Polycirrinae (Malmgren) }
$$

Polycirridae Malmgren, 1865: 390.-Caullery, 1944: 189-191. Polycirrinae Hessle, 1917: 219.

Description. Expanded tentacular membrane. Branchiae absent. Notopodia if present with capillary 